\title{
Evaluation of pulmonary functions in alternate fuel users
}

\author{
B. Jaya ${ }^{1, *}$, A. Sornam ${ }^{2}$, S. Vadivel ${ }^{3}$, M. Geetha ${ }^{4}$ \\ ${ }^{\mathbf{1}}$ Assistant Professor, ${ }^{2} \mathrm{MBBS}$ Student, ${ }^{\mathbf{3}} \mathrm{HOD},{ }^{\mathbf{4}}$ Associate Professor, ${ }^{\mathbf{1}, 2,3}$ Dept. of Physiology, ${ }^{4}$ Dept. of Community Medicine, \\ Karpaga Vinayaga Institute of Medical Sciences and Research Centre, Kanchipuram, Tamil Nadu, India
}

*Corresponding Author:

Email: madujaya@ hotmail.com

Received: $17^{\text {th }}$ March, 2018
Accepted: $28^{\text {th }}$ March, 2018

\begin{abstract}
Introduction: Indoor air pollution is present in rural areas due to usage of biomass fuel like wood, dung or crop residues for cooking. The rural women are exposed to the smoke produced by combustion of these materials, which can cause harmful effects to the respiratory system. The present study was done to evaluate the lung functions in women exposed to biomass fuel smoke for chronic period.

Materials and Methods: The case control study included 102 female subjects, divided into two age matched groups of 52 biomass fuel users and 50 Liquefied Petroleum Gas (LPG) users. Pulmonary function tests (PFT) namely Forced vital capacity (FVC), Forced expiratory volume in one second $\left(\mathrm{FEV}_{1}\right)$, Forced expiratory flow $\left(\mathrm{FEF}_{25-75 \%}\right)$ and Forced expiratory volume percentage $\left(\mathrm{FEV}_{1} \%\right)$ were assessed by computerized spirometry. Statistical comparison was done by using the student t-test.'

Results: The percentage predicted value of the lung parameters of the biomass fuel users $\left[\mathrm{FVC}(\mathrm{p}<0.01), \mathrm{FEV}_{1}(\mathrm{p}<0.01), \mathrm{FEF} 25-\right.$ $75 \%(\mathrm{p}<0.01)$ and $\mathrm{FEV}_{1} \%(\mathrm{p}<0.01)$ were reduced significantly in biomass fuel users as compared to those using LPG.

Conclusion: The results of this study suggest that exposure to biomass fuel smoke for chronic period can lead to reduction in lung function. This study also shows the importance of interventions required to improve the standard of living conditions like usage of low smoke fuels.
\end{abstract}

Keywords: Biomass fuel users, Liquefied petroleum gas users, Computer spirometry, Pulmonary function test.

\section{Introduction}

Urbanisation has resulted in air pollution due to gases from industrial smoke and vehicle exhaust. This pollution is also present in rural areas of India due to the use of burning of biomass fuel for household cooking. About $90 \%$ of the primary energy is derived from this solid fuel which includes predominantly firewood followed by dung and crop residues. ${ }^{1}$

More than 3 billion people, comprising about half the world's population, use this biomass fuel to meet their basic household energy requirements, and a large proportion of this exposed population reside in less economically developed countries. ${ }^{2}$ In rural India, women undertake routine cooking and heating over long periods, often many hours per day, and tend to be exposed to much higher levels of indoor air pollutants than men living in the same household. ${ }^{3}$ And also in these areas, $90 \%$ of the women involved in cooking expose themselves to a high pollution levels because the houses are poorly ventilated and most of them have no separate kitchens. ${ }^{4}$

Studies have shown that an average woman in India may be subjected to approximately 60,000 hours of exposure to indoor smoke due to combustion of biomass fuels in her life time. This includes both the concentration of the pollutants and time spent by the person in that environment. A simple, easily applicable method is "biomass exposure index" which can be calculated by multiplying the average hours spent on cooking per day and the number of years of cooking. ${ }^{5}$
Burning of biomass fuel generates suspended particles which can be inhaled. Also incomplete combustion leads to high indoor concentration of carbon monoxide, nitrogen oxide, polycyclic hydrocarbons which are harmful to health. ${ }^{6}$ This may lead to acute respiratory infections, bronchitis, chronic obstructive lung disease etc. A cross sectional survey conducted in a village in western India in 2005 showed a strong link of exposure to biomass smoke and impairment of lung function. ${ }^{7}$ Long term exposure to these particles has been strongly linked to reduction in pulmonary function parameters, suggestive of airway obstruction. ${ }^{8,9}$

The studies on effects of indoor air pollution in developing countries have reported that the use of solid fuel increases the risk of acquiring Chronic Obstructive Pulmonary Disease (COPD). There was mild to moderate reduction in spirometric variables such as $\mathrm{FEV}_{1}$ which is a measure of obstructive airway disease. ${ }^{10,11}$

To measure the intensity of health hazards of Biomass fuel on lung function the present study was conducted by comparing the pulmonary function test in females using this fuel, with that of a group of control women who were using Liquefied Petroleum Gas (LPG).

\section{Aims and Objectives}

1. To record the details of kitchen, type of fuel used and the number of cooking hours per day. 
2. To measure the Pulmonary Function Test (PFT) in women exposed to biomass fuel. They were chosen as cases.

3. To measure the PFT in women using LPG. They were chosen as controls.

4. To compare the PFT in women using biomass for cooking to those using LPG

\section{Materials and Methods}

The study was conducted in women living in the village around the area of the Medical institution. After obtaining clearance from Institutional Ethical Committee, 52 female subjects who use biomass fuel and 50 female subjects who use LPG as fuel, ranging between 25-45 years of age were chosen for the study. Informed consent was obtained from them. These subjects were interviewed with a standard respiratory questionnaire based on the American Thoracic Society Questionnaire and the European Respiratory Society (ATS/ERS). ${ }^{12}$ The methodology was communicated and the questionnaire was translated to them in their local language on a one to one basis. The details included the socioeconomic status, education, description of the cooking area, etc.

Medical history included history of upper and lower respiratory infections. Subjects who were pregnant,or those with the history of any major illness or recent surgery or those who were less than 25 and more than 45 years of age were excluded from the study.

After clinical examination which included height and weight, Pulmonary Function Test using "Medicaid Spiro Excel PC" based Pulmonary function system was done on all subjects. ${ }^{13}$ The entire procedure was explained and demonstrated satisfactorily to the subjects. After attaching nose clips, the subjects were asked to take maximal inspiration and blow into the mouthpiece as rapidly, forcefully and completely as possible for about at least 4 seconds. A minimum of 3 acceptable Forced vital capacity (FVC) manoeuvres was performed in the standing position with nose pinched and the best curve was selected and accepted. The FVC, $\mathrm{FEV}_{1}, \mathrm{FEV}_{1} \%$, and Forced Expiratory Flow Rate $\left(\mathrm{FEF}_{25-75 \%}\right)$ was measured on all subjects.

Data of the various parameters were collected and statistical analysis was performed with the SPSS software. Student ' $t$ ' test was used for comparing the results between the groups.

\section{Results and Discussion}

The samples included 52 cases and 50 controls. The mean of age and Body Mass Index (BMI) of the cases and controls are shown in table 1. The two groups were comparable in age and BMI.21\% of biomass group and $24 \%$ of the LPG group had history of passive smoking. There was no comparable difference between the groups pertaining to habits of tobacco or betel nut usage.

The demographic details of the subject are shown in table 2. Most of the biomass users were living in kutcha houses using common kitchen and a significant number of them had no proper ventilation. Many of them were illiterate compared to the LPG users. Most of the LPG users were living in pucca and semi pucca houses and were using separate kitchen while cooking. Both case and controls have been exposed to their respective fuels while cooking, for the past 15-20 years at an average of 2-3 hours per day. A significant number of the biomass users had episodes of lacrimation, rhinitis, cough and expectoration.

The mean and the percentage $(\%)$ predicted values of pulmonary function test values of biomass users and controls are shown in table 3 .

The percentage $(\%)$ predicted values of $\mathrm{FEV}_{1}$, $\mathrm{FVC}$, and $\mathrm{FEF}_{25-75 \%}$ of biomass users were significantly impaired compared to LPG users $(\mathrm{p}<0.01)$. Also the $\mathrm{FEV}_{1} \%$ values $(\mathrm{p}<0.01)$ of the biomass group was lesser than the LPG group. About $65.3 \%$ of the biomass users showed obstructive type of lung impairment compared to $8 \%$ among the LPG users.

Table 1: Anthropometric parameters of the subjects

\begin{tabular}{|l|c|c|}
\hline \multicolumn{1}{|c|}{ Variables } & $\begin{array}{c}\text { Biomass users }(\mathbf{n}=\mathbf{5 2}) \\
(\text { Mean } \pm \text { SD) }\end{array}$ & $\begin{array}{c}\text { LPG users }(\mathbf{n}=\mathbf{5 0}) \\
(\text { Mean } \pm \text { SD) }\end{array}$ \\
\hline Age (years) & $34.56 \pm 5.52$ & $34.68 \pm 6.39$ \\
\hline Body mass index $\left(\mathrm{Kg} / \mathrm{m}^{2}\right)$ & $22.61 \pm 3.32$ & $23.52 \pm 3.02$ \\
\hline
\end{tabular}

Table 2: Demographic details of the subjects

\begin{tabular}{|l|c|c|}
\hline \multicolumn{1}{|c|}{ Variables } & $\begin{array}{c}\text { Biomass users } \\
(\mathbf{n = 5 2})\end{array}$ & $\begin{array}{c}\text { LPG users } \\
(\mathbf{n = 5 0})\end{array}$ \\
\hline Literacy status & $12(23.1 \%)$ & $43(86 \%)$ \\
\hline Type of house & Kutcha $-25(48.1 \%)$ & Kutcha - 4 (8\%) \\
& Pucca $-5(9.6 \%)$ & Pucca- 23 (46\%) \\
& Semi pucca - 22(42.3\%) & Semi pucca - 23(46\%) \\
\hline Separate Kitchen & Separate - 32 (61.5\%) & Separate - 45 (90\%) \\
\hline Adequate ventilation & $25(48.1 \%)$ & $45(90 \%)$ \\
\hline
\end{tabular}


Table 3: Mean pulmonary function test parameters of the subjects

\begin{tabular}{|c|c|c|c|c|c|}
\hline \multirow{2}{*}{ Parameter } & \multicolumn{2}{|c|}{ Biomass users $(\mathrm{n}=52)$} & \multicolumn{2}{|c|}{ LPG users $(n=50)$} & \multirow{2}{*}{$\begin{array}{c}\text { Student 't } \\
\text { test } \\
\text { p value }\end{array}$} \\
\hline & $\begin{array}{c}\text { Test value } \\
\text { (Mean } \pm \text { SD) }\end{array}$ & $\begin{array}{c}\text { \% Predicted } \\
\text { value (Mean } \\
\pm \mathrm{SD})\end{array}$ & $\begin{array}{c}\text { Test value } \\
(\text { Mean } \pm \text { SD) }\end{array}$ & $\begin{array}{c}\text { \%Predicted } \\
\text { value (Mean } \\
\pm \text { SD) }\end{array}$ & \\
\hline $\mathrm{FEV}_{1}$ (litres) & $1.48 \pm 0.16$ & $76.13 \pm 6.54$ & $1.82 \pm 0.20$ & $89.43 \pm 5.44$ & $p<0.01(\mathrm{~S})$ \\
\hline FVC (litres) & $1.88 \pm 0.2$ & $80.1 \pm 5.44$ & $2.13 \pm 0.24$ & $88.94 \pm 4.88$ & $\mathrm{p}<0.01(\mathrm{~S})$ \\
\hline $\mathrm{FEV}_{1} \%$ & $78.88 \pm 4.91$ & $95.21 \pm 7.69$ & $85.51 \pm 6.53$ & $100.73 \pm 6.53$ & $\mathrm{p}<0.01(\mathrm{~S})$ \\
\hline $\begin{array}{l}\text { FEF } 25-75 \% \\
\text { (litres/sec) }\end{array}$ & $2.73 \pm 0.23$ & $80.95 \pm 4.95$ & $3.18 \pm 0.26$ & $95.04 \pm 6.67$ & $\mathrm{p}<0.01(\mathrm{~S})$ \\
\hline
\end{tabular}

The present study was undertaken to analyse the effect of biomass fuel on Lung function test. In this study the $\%$ predicted values of $\mathrm{FEV}_{1}, \mathrm{FVC}$ and $\mathrm{FEV}_{1} \%$ of the biomass users were found to be significantly lower than the LPG users. The percentage predicted value of $\mathrm{FEF}_{25-75 \%}$ of the biomass users were decreased significantly, suggesting obstruction of airways. The results of the present study show that chronic exposure to biomass fuel can have a detrimental effect on lung functions.

Today, indoor air pollution ranks $10^{\text {th }}$ among preventable risk factors contributing to the global burden of disease. ${ }^{14}$ The results from a study conducted in southern India reported a higher prevalence of COPD among biomass fuel user than clean fuel users. Also they observed that the prevalence was two times higher in women spending more than 2 hours a day in cooking. ${ }^{15}$

Biomass smoke constituents can produce acute and chronic biologic, physiologic, and structural effects in exposed animal models including decreased lung compliance, pulmonary edema $\&$ lung cancer as shown by experimental studies. ${ }^{16}$ Also vast majority of attributable deaths in humans from COPD \& lung cancer due to exposure to biomass fuel has been observed by Smith et al. ${ }^{17}$

The constituents of biomass smoke are particulate matter of less than $10 \mu \mathrm{m}$ in aerodynamic diameter (PM10), carbon monoxide, nitrogen dioxide, sulphur dioxide, formaldehyde, and polycyclic organic matter, including carcinogens (e.g., benzopyrene). ${ }^{16}$ Such particles and particularly those with a diameter smaller than $2.5 \mu \mathrm{m}$ (PM2.5), can penetrate deeply into the lungs and appear to have the greatest potential for damaging health. Polycyclic aromatic hydrocarbons have also been found to be potentially carcinogenic. Formaldehyde affects respiratory system causing reduction in vital capacity and chronic bronchitis. Toxic inorganic chemicals are known to cause asphyxiation, stillbirth, infant death, heart disease, and severe acute and chronic lung disease and their mechanisms of cell injury are still unexplained. ${ }^{17}$

In a cross sectional study in Mid Anatolia significant reduction in $\mathrm{FEV}_{1}, \mathrm{FVC}$, and $\mathrm{FEF}_{25-75 \%}$ was observed in biomass users. ${ }^{18}$ Ekici et al showed that prevalence of chronic airway disease was high in exposed group compared to control. ${ }^{19}$
Respiratory symptoms especially phlegm and cough, has been consistently higher due to the inhalation of particulate matter in women cooking with biomass fuels in comparison with those using cleaner fuels like LPG. ${ }^{20,8,21}$ The biomass users who used firewood had significantly more cough than liquefied petroleum gas (LPG), and electricity users. ${ }^{21}$ The biomass users in the present study also had upper and lower respiratory symptoms.

Cross-sectional studies show a mild to moderate reductions of the $\mathrm{FEV}_{1} \%$ and $\mathrm{FEF}_{25-75 \%}$ with the exposure to indoor biomass burning., ${ }^{7,8}$ A study on effect of firewood smoke on women of Bogota had shown the association with obstructive airway disease. ${ }^{22}$ Certain case-control studies, confirm that people exposed to biomass smoke have a high risk for developing airflow obstruction with significant reduction of $\mathrm{FEV}_{1}$ and $\mathrm{FEV}_{1} \%$. $^{23,24,19}$ The results of the present study also indicate that exposure to biomass smoke for prolonged period causes impairment of lung functions leading to airway obstruction.

\section{Conclusion}

The present study was undertaken to measure the effect of biomass smoke on lung functions by comparing with a group of Control women using LPG. Female subjects who use biomass fuel and subjects using LPG, of the age group 25 to 45 years were chosen for the study. After detailed questionnaire, pulmonary function test using Medicaid Spiro Excel PC was done and the values were analysed. The association between the use of biomass fuel and the decrease in certain lung function parameters like FVC $(\mathrm{P}<0.01), \quad \mathrm{FEF}_{25-75 \%}$ $(p<0.01)$ and $\mathrm{FEV}_{1} \% \quad(\mathrm{p}<0.01)$ were found to be significant compared to the controls. Thus the study suggests the association of usage of biomass fuels with impairment of lung functions.

The findings of this study shows an insight regarding status of cooking practices and effect of all these on the pulmonary function tests and respiratory health. This study also shows the importance of interventions required to improve the standard of living conditions like the need to use low smoke fuels. The purpose of the present study was also meant to educate the public about the healthier cooking practices like better ventilation and usage of face mask while using biomass fuel. 


\section{References}

1. TEDDY: Tata Energy Data Directory Yearbook 19981999. New Delhi: Tata Energy Research Institute.

2. Rehfuess E, World Health Organization. Fuel for life: household energy and health.

3. Balakrishnan K, Ramaswamy P, Sambandam S, Thangavel G, Ghosh S, Johnson P, Mukhopadhyay K, Venugopal V, Thanasekaraan V. Air pollution from household solid fuel combustion in India: an overview of exposure and health related information to inform health research priorities. Global health action. 2011;4(1). doi: 10.3402/gha.v4i0.5638

4. UNDP W, Legros G, Havet I, Bruce N, Bonjour S, Rijal $\mathrm{K}$, Takada M, Dora C. The energy access situation in developing countries. New York. 2009.

5. Behera D, Jindal SK. Respiratory symptoms in Indian women using domestic cooking fuels. Chest. 1991 Aug 1;100(2):385-8.

6. Smith KR, Indoor pollution in developing countries, recommendations for research, Indoor Air. 2002;12:198207.

7. Saha A, Rao NM, Kulkarni PK, Majumdar PK, Saiyed HN. Pulmonary function and fuel use: a population survey. Respiratory research. 2005 Dec;6(1):127.

8. Regalado J, Pérez-Padilla R, Sansores R, Paramo Ramirez JI, Brauer M, Paré P, Vedal S. The effect of biomass burning on respiratory symptoms and lung function in rural Mexican women. Am J Respir Crit Care Med. 2006 Oct 15;174(8):901-5.

9. Padhi BK, Padhy PK. Domestic fuels, indoor air pollution, and children's health. Ann N Y Acad Sci. 2008 Oct 1;1140(1):209-17.

10. Smith KR, Mehta S. The burden of disease from indoor air pollution in developing countries: comparison of estimates. Int J Hyg Environ Health. 2003 Aug;206(45):279-89.

11. Bruce N, Perez-Padilla R, Albalak R, World Health Organization. The health effects of indoor air pollution exposure in developing countries.

12. Brusasco EV, Crapo R, Viegi G, Wanger J, Clausen JL, Coates A, Pedersen OF, Brusasco V, Burgos F, Casaburi R, Enright P. Series "ATS/ERS task force: standardisation of lung function testing".

13. Revathi M, Kutty TK, Annamalai N. Pulmonary function in rural women exposed to biomass fuel. J Pulmon Resp Med. 2012;2(7):1-4.

14. World Health Organization. The world health report 2002: reducing risks, promoting healthy life. World Health Organization; 2002.

15. Johnson P, Balakrishnan K, Ramaswamy P, Ghosh S, Sadhasivam M, Abirami O, Sathiasekaran BW, Smith KR, Thanasekaraan V, Subhashini AS. Prevalence of chronic obstructive pulmonary disease in rural women of Tamilnadu: implications for refining disease burden assessments attributable to household biomass combustion. Global health action. 2011 Dec 1;4(1):7226.

16. Naeher LP, Brauer M, Lipsett M, Zelikoff JT, Simpson CD, Koenig JQ, Smith KR. Woodsmoke health effects: a review. Inhalation toxicology. 2007 Jan 1;19(1):67-106.

17. Smith KR, Mehta S, Maeusezahl-Feuz M. Indoor air pollution from household use of solid fuels. Comparative quantification of health risks: global and regional burden of disease attributable to selected major risk factors. 2004;2:1435-93.

18. Sümer H, Turaçlar UT, Onarlioglu T, Özdemir L, Zwahlen M. The association of biomass fuel combustion on pulmonary function tests in the adult population of Mid-Anatolia. Sozial-und Präventivmedizin/Social and Preventive Medicine. 2004 Aug 1;49(4):247-53.

19. Ekici A, Ekici M, Kurtipek E, Akin A, Arslan M, Kara T, Apaydin Z, Demir S. Obstructive airway diseases in women exposed to biomass smoke. Environmental Research. 2005 Sep 1;99(1):93-8.

20. 20 Shrestha IL, Shrestha SL. Indoor air pollution from biomass fuels and respiratory health of the exposed population in Nepalese households. International journal of occupational and environmental health. $2005 \mathrm{Apr}$ 1;11(2):150-60.

21. Ellegård A. Cooking fuel smoke and respiratory symptoms among women in low-income areas in Maputo. Environmental health perspectives. 1996 Sep;104(9):980.

22. Dennis RJ, Maldonado D, Norman S, Baena E, Martinez G. Woodsmoke exposure and risk for obstructive airways disease among women. Chest. 1996 Jan 1;109(1):115-9.

23. Raj TJ. Altered lung function test in asymptomatic women using biomass fuel for cooking. Journal of clinical and diagnostic research: JCDR. 2014 Oct;8(10):BC01-3.

24. Perez-Padilla R, Regalado J, Vedal S, Paré P, Chapela R, Sansores R, Selman M. Exposure to biomass smoke and chronic airway disease in Mexican women. A casecontrol study. Am J Respir Crit Care Med. 1996 Sep;154(3):701-6.

How to cite this article: Jaya B, Sornam A, Vadivel S, Geetha M. Evaluation of pulmonary functions in alternate fuel users. Ind J Clin Anat Physiol. 2018;5(3):295-298. 